\title{
Genotype and environment interaction on soybean yield in Mato Grosso State, Brazil
}

\author{
José Francisco Ferraz de Toledo(1), Cláudio Guilherme Portela de Carvalho(1), Carlos Alberto Arrabal Arias ${ }^{(1)}$, \\ Leones Alves de Almeida ${ }^{(1)}$, Rodrigo Luis Brogin ${ }^{(1)}$, Marcelo Fernandes de Oliveira ${ }^{(1)}$, \\ José Ubirajara Vieira Moreira ${ }^{(1)}$, Aliny Simony Ribeiro(1) and Dario Minoru Hiromoto ${ }^{(2)}$
}

(1)Embrapa Soja, Caixa Postal 231, CEP 86001-970, Londrina, PR. E-mail: toledo@cnpso.embrapa.br, cportela@cnpso.embrapa.br, arias@cnpso.embrapa.br, leones@cnpso.embrapa.br, rodrigo@cnpso.embrapa.br, marcelo@cnpso.embrapa.br, bira2@cnpso.embrapa.br, aliny@cnpso.embrapa.br (2)Fundação MT, Caixa Postal 79, CEP 78705-040 Rondonópolis, MT. E-mail: fundacaomt@fundacaomt.com.br

\begin{abstract}
The objective of this work was to investigate the genotype-environment interaction in Mato Grosso State, MT. The relative importance of locations, years, sowing dates and cultivars and their interactions was analyzed from data collected in regional yield trials performed in a randomized complete block design with four replications, from 1994-1995 through 1999-2000, in nine locations and two sowing dates. Individual and pooled analyses of variance over years and locations were performed. Complementary analyses of variances partitioned MT State in two main and five smaller regions, respectively: North and South of Cuiabá; and MT-South-A (Pedra Preta area), MT-South-B (Rondonópolis and Itiquira), MT-East (Primavera do Leste and Campo Verde), MTCentral (Nova Mutum, Lucas do Rio Verde and Sorriso) and MT-Parecis (Campo Novo dos Parecis and Sapezal). Locations are relatively more important than years for yield testing soybeans in the MT State, therefore, investment should be made in increasing locations rather than years to improve experimental precision. Partitioning the MT State into regions has little impact on soybean yield testing results and, consequently, on the efficiency of the soybean breeding program in the State. Breeding genotypes with broad adaptation for the MT State is an efficient strategy for cultivar development.
\end{abstract}

Index terms: Glycine max, plant breeding, plant genetics, soybean adaptation.

\section{Interação de genótipos com ambientes e produtividade da soja no Estado do Mato Grosso, Brasil}

\begin{abstract}
Resumo - O objetivo deste trabalho foi investigar a interação de genótipos com ambientes no Estado do Mato Grosso, MT. Locais, anos, épocas de semeadura, cultivares e respectivas interações foram analisados em relação a dados de produtividade de grãos de ensaios regionais realizados em delineamento de blocos completos casualizados, conduzidos de 1994-1995 a 1999-2000, em nove locais e duas épocas de semeadura. Análises de variâncias individuais e conjuntas de anos e locais foram efetuadas. Análises complementares foram realizadas, dividindo o Estado em duas regiões principais e cinco regiões menores, respectivamente: Norte e Sul de Cuiabá; e MT-Sul-A (área de Pedra Preta), MT-Sul-B (Rondonópolis e Itiquira), MT-Leste (Primavera do Leste e Campo Verde), MT-Central (Nova Mutum, Lucas do Rio Verde e Sorriso) e MT-Parecis (Campo Novo dos Parecis e Sapezal). Locais foram relativamente mais importantes que anos na produtividade da soja, portanto, deverá haver investimento no aumento do número de locais ao invés de anos a fim de melhorar a precisão experimental. A divisão do Estado em regiões tem pequeno impacto nos resultados de produtividade e, conseqüentemente, na eficiência do programa de melhoramento. Desenvolver genótipos com ampla adaptação é uma estratégia eficiente de melhoramento da soja para o Estado.
\end{abstract}

Termos para indexação: Glycine max, melhoramento de plantas, genética de plantas, adaptação de soja.

\section{Introduction}

Cropping 5.1 million ha and harvesting 14.5 million ton of soybean in 2003/2004 ranked Mato Grosso State (MT State) in first place in area, production and yield among the Brazilian growing States. Most of the State is suitable for soybean cropping but producing areas are concentrated in the regions roughly limited by the counties Campo Verde, Primavera do Leste, Itiquira and Alto Taquari, in the South, and Nova Mutum, Sorriso and Sapesal, in the Center West. High yielding and highly adapted cultivars coupled with cropping technology 
custom developed for the region were the main factors behind the success. Cultivars for the MT State were released for cultivation after breeding and extensive fieldtesting in the regions during the last ten years.

Breeding soybean genotypes for cropping in such extensive areas requires careful considerations about genotype and environment ( $\mathrm{GxE}$ ) interaction to optimize results, since its effects may slow down the identification of the superior cultivars (Allard \& Bradshaw, 1964; Arantes, 1979). GxE interaction is dealt with either by selection of broad adaptation cultivars or by stratification of the production area and release of cultivar specifically adapted to each stratum (Ramalho et al., 1993).

Soybean breeding programs carried out by Embrapa usually aim at developing high yielding cultivars with the widest achievable adaptation to simplify the choice of cultivar and the seed production procedures.

In spite of the continuous increase in the cropped area in the MT State, two main soybean-growing regions prevail, namely, to the North and South of the capital Cuiabá, basically because of photoperiod (latitude), physical separation due to geography and predominant climatic conditions. They may also be subdivided into five smaller regions, grouped by altitude, soil class or latitude [MT-South-A (Pedra Preta area), MT-South-B (Rondonópolis and Itiquira areas), MT-East (Primavera do Leste and Campo Verde area), MT-Central (Nova Mutum, Lucas do Rio Verde and Sorriso area) and MTParecis (Campo Novo dos Parecis and Sapezal area)].

The objective of this work was to investigate and report types of genotype and environment interactions present in Mato Grosso State soybean cropping regions using data from yield trials performed during six years and to check if the stratification of the State in different areas for cultivar indication is necessary or desirable for cultivar development.

\section{Material and Methods}

Yield data were collected from the soybean regional yield trials carried out for Mato Grosso (MT) State by the partnership between Embrapa and Fundação Mato Grosso from the 1994-1995 to 1999-2000 growing seasons. Main characteristics of the trial locations are shown in Table 1 . The specific trial location frequently varied within a single county from year to year, but the main characteristics of the location are expected to remain largely unchanged.
The trials involved a total of about ninety cultivars and breeding lines and were divided in three maturity groups: early - Conquista, Pioneira, Itiquira, Paiaguás, DM 247, FT 109, Emgopa 313, Emgopa 315, FT 110, FT Estrela, IAC 8, MTBR95-123246, UFV 16; medium - Paiaguás, Xingu, DM Vitória, Emgopa 313, FT 101, FT 105, FT 111, IAC 8, M-SOY 8400, MTBR92-33537, UFV 18; and late - Garça Branca, BR Campo Grande, Uirapuru, Tucano, DM 339, Emgopa 313, FT 106, FT 114, Cristalina, MTBR92-335538. Not all cultivars were tested in every location and some cultivars appeared as checks in more than one maturity group. Only the most regularly tested cultivars or breeding lines, which in many opportunities were used as checks in the trials, were included in the calculation of the source of variation effects. The purpose was to reduce data unbalance that, nevertheless, remained high in some cases. Experimental data from 1994-1995, 1995-1996 and 1996-1997 involved sowings in mid November, while data from 1997-1998, 1998-1999 and 1999-2000 involved sowings of mid November and early December.

Analyses of means and variances were performed individually for each year and location and also involved joint assessment of years within locations, locations within years and years and locations altogether. Further analyses were carried out after dividing the MT State in two and five regions. The partition of the MT State in two regions considered the two main large cropping areas roughly divided into North and South of Cuiabá, which represent different latitudes and climatic conditions of the Cerrado (South) and pre-Amazon (North) weather conditions. The second partition resulted in five regions, considering the soil, latitude and altitude characteristics of these smaller areas, which were: MT-South-A (Pedra Preta area), MT-South-B (Rondonópolis and Itiquira areas), MT-East (Primavera do Leste and Campo Verde

Table 1. Data of the field trials locations in Mato Grosso State, 1995-2000.

\begin{tabular}{|c|c|c|c|}
\hline Location & Latitude & Altitude $(\mathrm{m})$ & Soil class \\
\hline Rondonópolis & $16^{\circ} 42^{\prime} 16^{\prime \prime}$ & 450 & Rhodic Haplustox \\
\hline Pedra Preta & $16^{\circ} 50^{\prime} 23^{\prime \prime}$ & 740 & Rhodic Haplustox \\
\hline Itiquira & $17^{\circ} 25^{\prime} 45^{\prime \prime}$ & 522 & Rhodic Haplustox \\
\hline Primavera do Leste & $15^{\circ} 27^{\prime} 15^{\prime \prime}$ & 620 & Typic Haplustox \\
\hline Campo Verde & $15^{\circ} 20^{\prime} 28^{\prime \prime}$ & 726 & Rhodic Haplustox \\
\hline Lucas do Rio Verde & $13^{\circ} 32^{\prime} 07^{\prime \prime}$ & 477 & Rhodic Haplustox \\
\hline Sorriso & $12^{\circ} 32^{\prime} 43^{\prime \prime}$ & 330 & Rhodic Haplustox \\
\hline Campo Novo dos Parecis & $13^{\circ} 38^{\prime} 51^{\prime \prime}$ & 570 & Typic Haplustox \\
\hline Sapezal & $13^{\circ} 28^{\prime} 14^{\prime \prime}$ & 560 & Rhodic Haplustox \\
\hline
\end{tabular}


area), MT-Central (Nova Mutum, Lucas do Rio Verde and Sorriso area) and MT-Parecis (Campo Novo dos Parecis and Sapezal area).

The experimental model of the individual analyses of variance was based on the randomized complete blocks design (RCBD) with four replications. Plots were formed by four $5 \mathrm{~m}$ rows. The two central rows trimmed to $4 \mathrm{~m}$ produced the useful plot area. The joint analyses of variance presented included joint analyses of years within each location; locations within each year; joint analyses of years and locations; of years and regions; and of years, locations and sowing dates, carried out on the adjusted means of the individual analysis (RCBD). The year, location and cultivar effects were considered random, while the region effect was fixed. Spearman's rank correlations (Steel \& Torrie, 1982) among cultivar means of years within locations and of locations within years were calculated.

\section{Results and Discussion}

Genotypes belonging to the late maturity group were higher yielding $\left(3,187 \mathrm{~kg} \mathrm{ha}^{-1}\right)$ at $5 \%$ of probability, than those belonging to the early and medium maturity groups, which were similar in yield, 3,013 $\mathrm{kg} \mathrm{ha}^{-1}$ and 3,041 $\mathrm{kg} \mathrm{ha}^{-1}$, respectively. The pattern of significance of the interactions among the genotypes with locations, years or environments, in the maturity groups, which are discussed in the next paragraphs, did not allow choice of any group as the most stable or best adapted to the MT State growing conditions. Similar studies on data from the regional yield trials of the Paraná State performed by Alliprandini et al. $(1994,1998)$ were more conclusive and indicated that the semi-early maturity group, which was equivalent to the medium maturity group, was the highest yielding and best adapted for the Paraná State cropping conditions.

The comparison of yield data from early-mid November and early December sowings for the early, medium and late maturity groups showed that earlier sowing results in higher yields than later sowing, with $3,048 \mathrm{~kg} \mathrm{ha}^{-1}$ versus $2,910 \mathrm{~kg} \mathrm{ha}^{-1}, 3,067 \mathrm{~kg} \mathrm{ha}^{-1}$ versus $2,975 \mathrm{~kg} \mathrm{ha}^{-1}$, and $3,255 \mathrm{~kg} \mathrm{ha}^{-1}$ versus $3,017 \mathrm{~kg} \mathrm{ha}^{-1}$, respectively. November and December yield means in all three comparisons were statistically different at 5\% of probability. Similar pattern was also observed in Goiás and Paraná States (Carraro et al., 1984; Urben Filho \& Souza, 1993; Triller \& Toledo, 1996; Toledo et al., 2000). The data indicated that soybean sowings should preferentially be carried out in November and should be delayed only if unavoidable.

Analyses of years within each location (Table 2) showed highly significant (1\% of probability) year effects for all maturity groups in Campo Novo dos Parecis and Pedra Preta and nonsignificant effects in Primavera do Leste. For the remaining four locations, year effects were significant for at least one maturity group.

Table 2. Analyses of variances of soybean yield in Mato Grosso State from 1994 to 2000. Joint analyses of years within locations for the early, medium and late maturity groups.

\begin{tabular}{|c|c|c|c|c|c|c|}
\hline \multirow{2}{*}{$\begin{array}{l}\text { Source of } \\
\text { variation }\end{array}$} & \multicolumn{2}{|c|}{ Early maturity } & \multicolumn{2}{|c|}{ Medium maturity } & \multicolumn{2}{|c|}{ Late maturity } \\
\hline & $\overline{\text { d.f. }}$ & M.S. & d.f. & M.S. & d.f. & M.S. \\
\hline & \multicolumn{6}{|c|}{ Campo Novo dos Parecis } \\
\hline Years (Y) & 5 & $2,051,941.1^{* *}$ & 5 & $1,590,358.3^{* *}$ & 4 & $922,108.7^{* *}$ \\
\hline Cultivar (C) & 8 & $1,062,441.1^{* *}$ & 10 & $741,015.1^{* *}$ & 10 & $683,965.9^{*}$ \\
\hline $\mathrm{Y} \times \mathrm{C}$ & 4 & $38,967.8^{\mathrm{ns}}$ & 2 & $296,867.4^{\mathrm{ns}}$ & 5 & $131,315.8^{\text {ns }}$ \\
\hline Exp. error & 105 & $251,622.8$ & 108 & $202,635.5$ & 136 & $298,585.5$ \\
\hline \multirow[t]{2}{*}{$\mathrm{CV}(\%)$} & & 18.2 & & 15.3 & & 17.1 \\
\hline & \multicolumn{6}{|c|}{ Campo Verde } \\
\hline Years (Y) & 2 & $370,825.5^{\mathrm{ns}}$ & 2 & $952,486.8^{*}$ & 1 & $1,843,641.7^{\mathrm{ns}}$ \\
\hline Cultivar (C) & 2 & $1,094,382.1^{*}$ & 2 & $1,213,987.4^{* *}$ & 2 & $52,910.6^{\mathrm{ns}}$ \\
\hline $\mathrm{Y} \times \mathrm{C}$ & 1 & $3,397.1^{\mathrm{ns}}$ & 1 & $4,560.1^{\mathrm{ns}}$ & 1 & $1,423,333.5^{* *}$ \\
\hline Exp. error & 18 & $281,586.3$ & 16 & $191,651.8$ & 21 & $115,580.6$ \\
\hline \multirow[t]{2}{*}{ CV $(\%)$} & & 14.2 & & 14.6 & & 11.3 \\
\hline & \multicolumn{6}{|c|}{ Lucas do Rio Verde } \\
\hline Years (Y) & 2 & $1,941,164.7^{\mathrm{ns}}$ & 2 & $2,578,722.0^{* *}$ & 1 & $2,755,528.2^{* *}$ \\
\hline Cultivar (C) & 2 & $633,712.8^{\text {ns }}$ & 2 & $231,836.8^{\text {ns }}$ & 2 & $254,025.1^{\mathrm{ns}}$ \\
\hline $\mathrm{Y} \times \mathrm{C}$ & 1 & $498,009.0^{*}$ & 1 & $10,486.2^{\text {ns }}$ & 1 & $333,294.9^{\text {ns }}$ \\
\hline Exp. error & 18 & $89,782.8$ & 19 & $70,818.3$ & 21 & $163,727.6$ \\
\hline \multirow[t]{2}{*}{ CV $(\%)$} & & 12.3 & & 13.9 & & 18.1 \\
\hline & \multicolumn{6}{|c|}{ Nova Mutum } \\
\hline Years (Y) & 5 & $908,610.2^{* *}$ & 5 & $112,260.7^{\mathrm{ns}}$ & 4 & $1,635,844.6^{\mathrm{ns}}$ \\
\hline Cultivar (C) & 9 & $3,462,871.8^{* *}$ & 10 & $622,156.0^{* *}$ & 10 & $458,922.1^{\mathrm{ns}}$ \\
\hline Y x C & 4 & $242,638.7^{\mathrm{ns}}$ & 2 & $349,557.5^{\mathrm{ns}}$ & 5 & $508,275.1^{* *}$ \\
\hline Exp. error & 64 & $241,793.9$ & 64 & $202,358.7$ & 79 & $126,401.8$ \\
\hline \multirow[t]{2}{*}{ CV (\%) } & & 16.8 & & 14.5 & & 10.5 \\
\hline & \multicolumn{6}{|c|}{ Pedra Preta } \\
\hline Years (Y) & 5 & $1,602,385.0^{* *}$ & 5 & $1,636,912.2^{* *}$ & 4 & $1,381,599.6^{* *}$ \\
\hline Cultivar (C) & 8 & $845,934.3^{* *}$ & 10 & $322,948.9^{\text {ns }}$ & 9 & $301,930.7^{* *}$ \\
\hline $\mathrm{Y} \times \mathrm{C}$ & 4 & $229,874.3^{\mathrm{ns}}$ & 2 & $25,225.3^{\mathrm{ns}}$ & 5 & $36,616.3^{\mathrm{ns}}$ \\
\hline Exp. error & 48 & $124,603.7$ & 51 & $201,950.0$ & 64 & $112,578.7$ \\
\hline \multirow[t]{2}{*}{ CV $(\%)$} & & 9.8 & & 15.2 & & 10.1 \\
\hline & \multicolumn{6}{|c|}{ Primavera do Leste } \\
\hline Years (Y) & 5 & $545,255.4^{\mathrm{ns}}$ & 4 & $278,375.4^{\mathrm{ns}}$ & 3 & $277,441.1^{\mathrm{ns}}$ \\
\hline Cultivar (C) & 11 & $434,999.9^{\text {ns }}$ & 8 & $421,601.4^{* *}$ & 8 & $300,920.6^{\mathrm{ns}}$ \\
\hline $\mathrm{Y} \times \mathrm{C}$ & 4 & $500,678.0^{\mathrm{ns}}$ & - & - & 2 & $86,336.4^{\mathrm{ns}}$ \\
\hline Exp. error & 55 & $255,676.6$ & 37 & $112,599.6$ & 45 & $156,928.8$ \\
\hline \multirow[t]{2}{*}{ CV $(\%)$} & & 15.6 & & 9.8 & & 12.0 \\
\hline & \multicolumn{6}{|c|}{ Rondonópolis } \\
\hline Years (Y) & 5 & $1,440,142.8^{* *}$ & 5 & $466,277.2^{\mathrm{ns}}$ & 4 & $167,369.7^{\mathrm{ns}}$ \\
\hline Cultivar (C) & 7 & $510,593.9^{\text {ns }}$ & 10 & $787,413.3^{* *}$ & 9 & $499,641.1^{\mathrm{ns}}$ \\
\hline $\mathrm{Y} \times \mathrm{C}$ & 4 & $345,801.6^{\mathrm{ns}}$ & 2 & $164,038.0^{\mathrm{ns}}$ & 6 & $327,645.8^{\text {ns }}$ \\
\hline Exp. error & 61 & $378,973.4$ & 73 & $249,838.4$ & 96 & $279,331.1$ \\
\hline CV $(\%)$ & & 19.5 & & 17.1 & & 16.9 \\
\hline
\end{tabular}

${ }^{n s}$ Nonsignificant. ${ }^{*}$ and ${ }^{* *}$ Significant at 5 and $1 \%$ of probability, respectively. 
The year x cultivar interaction was mostly not significant, but it was significant in three occasions, once for the early maturity group (in Lucas do Rio Verde) and twice for the late maturity group (in Campo Verde and Nova Mutum). These results indicated that cultivar evaluation was consistent along the years, especially after the mean analyses confirmed prevalence of absence of cultivar mean rank changes. Spearman's rank correlation among cultivar means of years within locations, average of the three maturity groups, was $r_{s}=0.98$, significant at $1 \%$ of probability.

The analyses of locations within years (Table 3) showed highly significant location effects in all six years

Table 3. Analyses of variances of soybean yield in Mato Grosso State from 1994 to 2000. Joint analyses of locations in years for the early, medium and late maturity groups.

\begin{tabular}{|c|c|c|c|c|c|c|}
\hline \multirow{2}{*}{$\begin{array}{l}\text { Source of } \\
\text { variation }\end{array}$} & \multicolumn{2}{|c|}{ Early maturity } & \multicolumn{2}{|c|}{ Medium maturity } & \multicolumn{2}{|c|}{ Late maturity } \\
\hline & $\overline{\text { d.f. }}$ & M.S. & d.f. & M.S. & d.f. & M.S. \\
\hline & \multicolumn{6}{|c|}{$1994 / 1995$} \\
\hline Location (L) & 8 & $940,956.4^{* *}$ & 7 & $627,063.9^{* *}$ & 7 & $1,661,126.3^{* *}$ \\
\hline Cultivar (C) & 5 & $362,337.0^{* *}$ & 1 & $3,293,707.0^{* *}$ & 1 & $4,052,960.0^{* *}$ \\
\hline $\mathrm{L} \times \mathrm{C}$ & 8 & $73,978.8^{\mathrm{ns}}$ & 7 & $112,395.2^{\mathrm{ns}}$ & 7 & $251,840.1^{\mathrm{ns}}$ \\
\hline Exp. error & 65 & $68,850.3$ & 54 & $55,901.8$ & 78 & $119,248.8$ \\
\hline \multirow[t]{2}{*}{$\mathrm{CV}(\%)$} & & 8.1 & & 8.4 & & 12.3 \\
\hline & \multicolumn{6}{|c|}{$1995 / 1996$} \\
\hline Location (L) & 8 & $3,423,377.3^{* *}$ & 8 & $2,617,982.2^{* *}$ & 8 & $2,631,512.9^{* *}$ \\
\hline Cultivar (C) & 1 & $1,932,666.5^{* *}$ & 1 & $3,681,492.2^{*}$ & 1 & $884,844.3^{\text {ns }}$ \\
\hline $\mathrm{L} \times \mathrm{C}$ & 8 & $188,832.3^{\mathrm{ns}}$ & 8 & $399,328.1^{*}$ & 8 & $420,166.2^{* *}$ \\
\hline Exp. error & 54 & $181,265.8$ & 50 & $143,291.6$ & 51 & $112,795.3$ \\
\hline \multirow[t]{2}{*}{ CV $(\%)$} & & 14.2 & & 12.6 & & 10.2 \\
\hline & \multicolumn{6}{|c|}{$1996 / 1997$} \\
\hline Location (L) & 8 & $4,982,932.5^{* *}$ & 8 & $2,868,322.4^{* *}$ & 8 & $3,694,264.4^{* *}$ \\
\hline Cultivar (C) & 1 & $345,174.8^{\mathrm{ns}}$ & 1 & $2,752,116.1^{*}$ & 1 & $237.3^{\mathrm{ns}}$ \\
\hline $\mathrm{L} \times \mathrm{C}$ & 8 & $406,977.1^{* *}$ & 8 & $291,470.1^{* *}$ & 8 & $37,030.7^{\mathrm{ns}}$ \\
\hline Exp. error & 53 & $121,773.6$ & 54 & $101,656.6$ & 53 & $158,032.6$ \\
\hline \multirow[t]{2}{*}{ CV $(\%)$} & & 13.1 & & 11.2 & & 12.8 \\
\hline & \multicolumn{6}{|c|}{$1997 / 1998$} \\
\hline Location (L) & 5 & $660,160.5^{* *}$ & 5 & $819,318.8^{* *}$ & 5 & $792,350.2^{* *}$ \\
\hline Cultivar (C) & 1 & $212,491.0^{\mathrm{ns}}$ & 1 & $2,325,183 \cdot 2^{* *}$ & 1 & $1,692,991.9^{* *}$ \\
\hline $\mathrm{L} \times \mathrm{C}$ & 5 & $108,281.0^{\mathrm{ns}}$ & 4 & $201,046.6^{\mathrm{ns}}$ & 5 & $151,233.9^{\mathrm{ns}}$ \\
\hline Exp. error & 62 & $156,598.5$ & 103 & $135,317.1$ & 167 & $183,100.1$ \\
\hline \multirow[t]{2}{*}{ CV $(\%)$} & & 11.6 & & 11.5 & & 12.4 \\
\hline & \multicolumn{6}{|c|}{$1998 / 1999$} \\
\hline Location (L) & 5 & $5,386,513.9^{* *}$ & 5 & $2,914,871.7^{* *}$ & 5 & $3,611,677.4^{* *}$ \\
\hline Cultivar (C) & 4 & $123,270.1^{\mathrm{ns}}$ & 4 & $1,545,050.3^{* *}$ & 5 & $473,081.8^{\mathrm{ns}}$ \\
\hline $\mathrm{L} \times \mathrm{C}$ & 20 & $345,672.6^{\mathrm{ns}}$ & 20 & $310,599.6^{\mathrm{ns}}$ & 25 & $312,968.1^{*}$ \\
\hline Exp. error & 111 & $299,487.5$ & 106 & $194,454.2$ & 128 & $195,713.7$ \\
\hline \multirow[t]{2}{*}{ CV $(\%)$} & & 16.6 & & 14.9 & & 14.2 \\
\hline & \multicolumn{6}{|c|}{$1999 / 2000$} \\
\hline Location (L) & 5 & $1,875,631.7^{* *}$ & 5 & $1,625256.4^{* *}$ & 5 & $2,349,761.2^{* *}$ \\
\hline Cultivar (C) & 5 & $8,291,950.1^{* *}$ & 4 & $256,918.7^{\mathrm{ns}}$ & 7 & $793,439.2^{*}$ \\
\hline $\mathrm{L} x \mathrm{C}$ & 22 & $436,783.5^{* *}$ & 20 & $218,449.1^{\mathrm{ns}}$ & 28 & $241,703.5^{*}$ \\
\hline Exp. error & 109 & $198,281.6$ & 101 & $206,746.5$ & 124 & $142,680.1$ \\
\hline CV $(\%)$ & & 14.4 & & 13.6 & & 11.0 \\
\hline
\end{tabular}

and three maturity groups. The interaction among locations and cultivars was not significant in 1994-1995 and 1997-1998. It was significant for the late maturity group at 5\% of probability in 1998-1999 and significant for two out of the three maturity groups in the remaining three years. The result clearly depicted the importance of the location effect in the expression of soybean yield. Significant location $\mathrm{x}$ cultivar interactions suggested that selection for wider genotype adaptation may be difficult. This picture also seemed to suggest that stratification of the MT State into more homogeneous regions could improve efficiency of the search for superior genotypes. Benefits could stem from an increase in the efficiency of selection of materials specifically adapted to each region or from a decrease in the number of locations required in the State yield trials by defining smaller homogeneous regions (Alliprandini et al., 1994; Carvalho et al., 2002; Murakami \& Cruz, 2004). In the MT State, however, analyses of cultivar means showed that significant interactions did not result from cultivar ranking changes, but rather from a prevalent less severe different relative performance in the locations, as could be depicted from Spearman's rank correlations $\left(\mathrm{r}_{\mathrm{s}}\right)$ among cultivar means of locations within years that were 0.76, 0.92 and 0.81 for the early, medium and late maturity groups, respectively, all significant at $1 \%$ of probability. This is an easier type of interaction to deal with (Cruz \& Regazzi, 1994), since the best genotypes are consistent along the several locations.

The joint analysis of years and locations was performed to further develop the knowledge about the performance of the genotypes in the MT State environments. In this analysis, the year effect was not significant for all three maturity groups, while the location effect remained significant at $5 \%$ of probability for the three maturity groups (Table 4). Year $\mathrm{x}$ location interaction effects were significant at $1 \%$ of probability for all groups. Considering that each location and year characterize a different environment, it may be assumed that cultivar yields were responding to environmental changes rather than specific location or year effects, which in the previous individualized analyses were characterized by the different years and locations. The triple year $\mathrm{x}$ location $\mathrm{x}$ cultivar interactions were not significant for the three maturity groups, suggesting absence of alterations in relative cultivar performance due to environmental effects stemming from combinations of years and locations. 
The year $\mathrm{x}$ cultivar interaction was significant at $5 \%$ of probability for the late maturity group, while the location $\mathrm{x}$ cultivar interaction was significant at $5 \%$ of probability for all maturity groups. Relative cultivar yield mean changes predominantly did not imply rank alterations among cultivar yields.

The fact that the combination of years and locations formed environments, which, in turn, did not change cultivar yield ranking facilitates testing genotypes in the MT State. However, the data also indicated that the location effect had a stronger impact on soybean cultivar yield than the year effect and, consequently, years and locations are not interchangeable. This means that if a given amount of resources is to be applied in soybean yield testing in the MT State, the breeder should prefer to increase the number of locations rather than years. This is a different result from that reported by Alliprandini et al. (1994) for the Paraná State, where year and locations were readily interchangeable to form environments for soybean yield testing. The relative higher importance of locations over years in the MT State comparatively to the Paraná State may be explained by the fact that the rainfall is more regularly distributed in MT than in Paraná, which is in a climatic transition region. Rainfall regularity along the years most likely rendered less important years than locations effects for soybean yield expression in MT.

Partitioning the MT State into two or five regions with hypothetically more homogeneous characteristics corroborated previous reasoning in which environment and not GxE interaction is the main factor to consider while yield testing soybeans. Partitioning the State into two large or five smaller regions rendered not significant

Table 4. Analyses of variances of soybean yield in Mato Grosso State from 1994 to 2000. Joint analyses of years and locations for the early, medium and late maturity groups.

\begin{tabular}{|c|c|c|c|c|c|c|}
\hline \multirow{2}{*}{$\begin{array}{l}\text { Source of } \\
\text { variation }\end{array}$} & \multicolumn{2}{|c|}{ Early maturity } & \multicolumn{2}{|c|}{ Medium maturity } & \multicolumn{2}{|c|}{ Late maturity } \\
\hline & d.f. & M.S. & d.f. & M.S. & $\overline{\text { d.f. }}$ & M.S. \\
\hline Years (Y) & 5 & $1,927,422.5^{\mathrm{ns}}$ & 5 & $1,263,795.7^{\mathrm{ns}}$ & 4 & $1,274,838.7^{\mathrm{ns}}$ \\
\hline Locations (L) & 6 & $3,358,211.7^{*}$ & 6 & $2,804,232.2^{*}$ & 6 & $3,819,382.4^{*}$ \\
\hline $\mathrm{Y} \times \mathrm{L}$ & 24 & $1,168,008.1^{* *}$ & 23 & $882,887.6^{* *}$ & 17 & $1,058,469.2^{* *}$ \\
\hline Cultivar (C) & 13 & $2,969,156.7^{* *}$ & 10 & $1,369,882.2^{* *}$ & 10 & $626,627.3^{\text {ns }}$ \\
\hline $\mathrm{Y} \times \mathrm{C}$ & 4 & $230,284.8^{\mathrm{ns}}$ & 2 & $12,218.9^{\mathrm{ns}}$ & 6 & $564,815.3^{*}$ \\
\hline $\mathrm{L} \times \mathrm{C}$ & 34 & $433,890.7^{*}$ & 42 & $325,835.9^{*}$ & 39 & $342,210.6^{*}$ \\
\hline Y x L x C & 18 & $313,106.5^{\text {ns }}$ & 8 & $176,414.4^{\mathrm{ns}}$ & 20 & $214,409.3^{\mathrm{ns}}$ \\
\hline Exp. error & 369 & $248,619.0$ & 368 & $195,520.1$ & 462 & $211,128.7$ \\
\hline CV $(\%)$ & & 16.4 & & 14.4 & & 14.1 \\
\hline
\end{tabular}

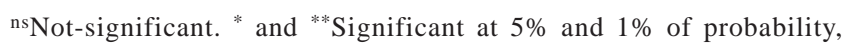
respectively. region or year main effects and significant region $\mathrm{x}$ year interaction effects and location $\mathrm{x}$ year within region interaction effects (Tables 5 and 6). Partitioning the State in only two regions still resulted in significant location within region effect, again showing the relatively stronger effect of locations comparatively to years. Partitioning into five regions intuitively would made regions substitute for locations, causing regions to become significant and locations within regions not significant. However, the region effect was not significant, reinforcing the

Table 5. Analyses of variances of soybean yield in Mato Grosso State from 1994 to 2000. Joint analyses of years and locations and regions (MT- South and MT - Center) for the early, medium and late maturity groups.

\begin{tabular}{|c|c|c|c|c|c|c|}
\hline \multirow{2}{*}{$\begin{array}{l}\text { Source of } \\
\text { variation }\end{array}$} & \multicolumn{2}{|c|}{ Early maturity } & \multicolumn{2}{|c|}{ Medium maturity } & \multicolumn{2}{|c|}{ Late maturity } \\
\hline & d.f. & M.S. & d.f. & M.S. & d.f. & M.S. \\
\hline Years (Y) & 5 & $1,998,836.4^{\mathrm{ns}}$ & 5 & $1,303,205.2^{\mathrm{ns}}$ & 4 & $733,155.9^{n}$ \\
\hline Region (R) & 1 & $1,675,936.6^{\mathrm{ns}}$ & 1 & $73,436.3^{\text {ns }}$ & 1 & $797,125.7^{\mathrm{n}}$ \\
\hline YxR & 5 & $676,849.2^{*}$ & 5 & $905,208.1^{* *}$ & 4 & $3,237,036.0^{*}$ \\
\hline Locations/R & 5 & $3,470,272.6^{*}$ & 5 & $3,112,999.0^{*}$ & 5 & $4,456,779.7^{*}$ \\
\hline Y x L/R & 19 & $1,209,780.5^{* *}$ & 18 & $873,259.3^{* *}$ & 13 & $681,005.5^{*}$ \\
\hline Cultivar (C) & 13 & $2,446,865.3^{* *}$ & 10 & $1,306,593.3^{* *}$ & 10 & $559,582.4$ \\
\hline $\mathrm{Y} \times \mathrm{C}$ & 4 & $303,988.2^{\mathrm{ns}}$ & 2 & $7,744.8^{\text {ns }}$ & 6 & $542,149.4^{*}$ \\
\hline $\mathrm{R} \times \mathrm{C}$ & 8 & $739,719.9^{* *}$ & 10 & $543,481.9^{* *}$ & 9 & $315,378.5^{\mathrm{n}}$ \\
\hline$Y \times R \times C$ & 4 & $468,073.7^{\mathrm{ns}}$ & 2 & $145,639.7^{\mathrm{ns}}$ & 6 & $76,934.7^{\mathrm{n}}$ \\
\hline $\mathrm{L} \times \mathrm{C} / \mathrm{R}$ & 26 & $372,981.8^{\mathrm{ns}}$ & 32 & $255,543.2^{\mathrm{ns}}$ & 30 & $362,642.6^{*}$ \\
\hline$Y \times L \times C / R$ & 14 & $287,977.5^{\text {ns }}$ & 6 & $153,555.4^{\mathrm{ns}}$ & 14 & $269,792.8$ \\
\hline Exp. error & 369 & $248,619.0$ & 368 & $195,520.1$ & 462 & $211,128.7$ \\
\hline CV (\%) & & 16.4 & & 14.4 & & 14.1 \\
\hline
\end{tabular}

Table 6. Analyses of variances of soybean yield in Mato Grosso State from 1994 to 2000. Joint analyses of years, locations and regions (MT-South-A, MT-South-B, MT-Center, MT-East and MT-Parecis) for the early, medium and late maturity groups.

\begin{tabular}{|c|c|c|c|c|c|c|}
\hline \multirow{2}{*}{$\begin{array}{l}\text { Source of } \\
\text { variation }\end{array}$} & \multicolumn{2}{|c|}{ Early maturity } & \multicolumn{2}{|c|}{ Medium maturity } & \multicolumn{2}{|c|}{ Late maturity } \\
\hline & d.f. & M.S. & d.f. & M.S. & d.f. & M.S. \\
\hline Years (Y) & 5 & $1,508,232.4^{\mathrm{ns}}$ & & $1,513,024.5^{\mathrm{ns}}$ & 4 & $674,500.8^{\mathrm{ns}}$ \\
\hline Region (R) & 4 & $3,217,481.4^{\mathrm{ns}}$ & & $2,469,246.0^{\mathrm{ns}}$ & 4 & $2,146,438.7^{\mathrm{ns}}$ \\
\hline $\mathrm{Y} \times \mathrm{R}$ & 17 & $1,310,128.6^{* *}$ & 17 & $890,316.9^{* *}$ & 14 & $1,579,828.0^{*}$ \\
\hline Locations/R & 6 & $2,803,643.3^{\mathrm{ns}}$ & 6 & $1,502,741.2^{\mathrm{ns}}$ & 6 & $2,859,209.9^{\mathrm{ns}}$ \\
\hline Y x L/R & 9 & $1,342,780.0^{* *}$ & & $1,630,927.9^{* *}$ & 5 & $748,562.3^{\text {ns }}$ \\
\hline Cultivar (C) & 13 & $2,849,065.4^{* *}$ & 10 & $1,468,409.5^{* *}$ & 11 & $686,008.3^{\text {ns }}$ \\
\hline $\mathrm{Y} \times \mathrm{C}$ & 4 & $276,463.6^{\mathrm{ns}}$ & 2 & $17,779.8^{\mathrm{ns}}$ & 5 & $402,831.4^{\mathrm{ns}}$ \\
\hline $\mathrm{R} \times \mathrm{C}$ & 30 & $441,910.8^{\mathrm{ns}}$ & 38 & $326,157.9^{* *}$ & 39 & $324,844.7^{\text {ns }}$ \\
\hline $\mathrm{Y} \times \mathrm{R} \times \mathrm{C}$ & 16 & $322,426.1^{*}$ & 7 & $199,864.8^{\text {ns }}$ & 15 & $304,712.5^{*}$ \\
\hline $\mathrm{L} \times \mathrm{C} / \mathrm{R}$ & 15 & $236,151.8^{\mathrm{ns}}$ & 16 & $189,374.1^{\mathrm{ns}}$ & 17 & $229,088.2^{\text {ns }}$ \\
\hline$Y \times L \times C / R$ & 6 & $129,904.5^{\mathrm{ns}}$ & 3 & $135,539 \cdot 1^{\mathrm{ns}}$ & 5 & $620,738.2^{* *}$ \\
\hline Exp. error & 345 & $187,615.6$ & 345 & $155,200.5$ & 436 & $157,634.7$ \\
\hline CV $(\%)$ & & 14.2 & & 12.8 & & 12.2 \\
\hline
\end{tabular}

${ }^{\mathrm{ns}}$ Nonsignificant. ${ }^{*}$ and ${ }^{* *}$ Significant at 5 and $1 \%$ of probability, respectively. 
importance of the combination of factors to form environments for soybean yield testing. One apparent benefit from partitioning would be the not significance of the location $\mathrm{x}$ cultivar within region interaction, which was significant only for the late maturity group in the two region case at $5 \%$ of probability. However, since the location $\mathrm{x}$ cultivar interactions predominantly did not imply rank alterations, there would be little advantage of program efficiency to compensate for the increased analysis complexity. Years $\mathrm{x}$ region interaction, which characterized environments, became significant for the three maturity groups. Partitioning the MT State in two or five regions added little useful information to the breeder's work, as one should expect if the predominant effect acting upon soybean yield was the combination of year and location effects, rather than their specific main effects. Planning and executing separate soybean breeding programs for the two larger regions may render the work more laborious and expensive but not more efficient. The most important consequence from these results was the support for the notion that breeding should be towards selection of broad adaptation genotypes.

Table 7 shows the analyses of variance of the 1997-1998, 1998-1999 and 1999-2000 experiments, which were sown in early-mid November and early

Table 7. Analyses of variances of soybean yield in Mato Grosso State from 1997 to 2000. Joint analyses of years, sowing dates and locations for the early, medium and late maturity groups.

\begin{tabular}{|c|c|c|c|c|c|c|}
\hline \multirow{2}{*}{$\begin{array}{l}\text { Source of } \\
\text { variation }\end{array}$} & \multicolumn{2}{|c|}{ Early maturity } & \multicolumn{2}{|c|}{ Medium maturity } & \multicolumn{2}{|c|}{ Late maturity } \\
\hline & d.f. & M.S. & $\overline{\text { d.f. }}$ & M.S. & $\overline{\text { d.f. }}$ & M.S. \\
\hline Years (Y) & 2 & $2,549,828.4^{\mathrm{nS}}$ & 2 & $3,795,301.22^{\mathrm{ns}}$ & 2 & $3,739,144.5^{\mathrm{ns}}$ \\
\hline Sowing date (S) & 1 & $11,688,062.3^{* *}$ & 1 & $16,688,996.4^{*}$ & 1 & $31,138,243.2^{*}$ \\
\hline $\mathrm{Y} \times \mathrm{S}$ & 2 & $1,865,534.5^{\mathrm{ns}}$ & 2 & $2,318,948.5^{\mathrm{ns}}$ & 2 & $3,733,836.8^{\mathrm{ns}}$ \\
\hline Locations (L) & 4 & $3,230,421.8^{\mathrm{ns}}$ & 4 & $3,573,409.1^{*}$ & 4 & $3,803,187.6^{*}$ \\
\hline Yx L & 8 & $1,346,805.7^{* *}$ & 8 & $977,276.8^{* *}$ & 8 & $1,307,472.0^{* *}$ \\
\hline$S \times L$ & 4 & $1,292,048.9^{\mathrm{ns}}$ & 4 & $2,858,916.9^{*}$ & 4 & $6,274,333.7^{* *}$ \\
\hline Y X S x L & 7 & $547,494.2^{*}$ & 7 & $1,002,583.4^{* *}$ & 7 & $1,197,995.8^{* *}$ \\
\hline Cultivar (C) & 7 & $6,527,755.2^{* *}$ & 8 & $1,146,895.0^{* *}$ & 9 & $811,547.9^{*}$ \\
\hline $\mathrm{YxC}$ & 3 & $39,019.2^{\mathrm{ns}}$ & 1 & $50,959.8^{\mathrm{ns}}$ & 4 & $355,661.7^{\mathrm{ns}}$ \\
\hline $\mathrm{S} \times \mathrm{C}$ & 5 & $40,779.2^{\mathrm{ns}}$ & 8 & $535,538.7^{\mathrm{ns}}$ & 8 & $454,545.4^{\mathrm{ns}}$ \\
\hline $\mathrm{L} \times \mathrm{C}$ & 26 & $518,723.5^{* *}$ & 32 & $296,992.4^{*}$ & 35 & $310,954.7^{* *}$ \\
\hline $\mathrm{Y} \times \mathrm{S} \times \mathrm{C}$ & 3 & $315,056.0^{\mathrm{ns}}$ & 1 & $125.0^{\mathrm{ns}}$ & 2 & $540,640.3^{\mathrm{ns}}$ \\
\hline$Y \times L \times C$ & 12 & $186,424.5^{\mathrm{ns}}$ & 4 & $87,040.3^{\mathrm{ns}}$ & 12 & $222,704.0^{\mathrm{ns}}$ \\
\hline $\mathrm{S} \times \mathrm{L} \times \mathrm{C}$ & 17 & $193,330.1^{\mathrm{ns}}$ & 27 & $331,195.3^{* *}$ & 28 & $289,312.2^{*}$ \\
\hline Yx S x Lx C & 9 & $336,296.7^{\mathrm{ns}}$ & 2 & $370,738.4^{\mathrm{ns}}$ & 6 & $164,144.3^{\mathrm{ns}}$ \\
\hline Exp. error & 295 & $240,602.6$ & 322 & $180,030.5$ & 435 & $183,587.0$ \\
\hline CV $(\%)$ & & 15.4 & & 13.3 & & 12.9 \\
\hline
\end{tabular}

December. The introduction of different sowing dates in the analyses of this work was justified by the fact that farmers often cannot sow all areas in the best period for maximum yield, which is usually accepted as from early to mid November. Sowing of some fields is frequently finished late in December. Late sowing may be a consequence of the large farming areas, rainfall pattern or other unpredictable factors and, almost invariably, result in poorer yields. Therefore, selecting genotypes with adaptation to longer sowing periods may contribute to the MT State soybean growing system. This is likely to be feasible, especially after Lima et al. (2000) successfully selected soybean inbred lines simultaneously for high yield and broad sowing period (from mid to late September to mid to late December) for Paraná State.

The sowing date main effect was significant (Table 7), but its introduction in the analyses changed little the previous picture of the relative higher importance of environments, predominantly influenced by the location, over the other components of variation. The year $\mathrm{x}$ location and year $\mathrm{x}$ sowing $\mathrm{x}$ location interactions and the sowing $x$ location and sowing $\mathrm{x}$ location $\mathrm{x}$ cultivar interactions were significant for all maturity groups and for the medium and late groups, respectively. The cultivar effect was significant for all maturity groups, locations were significant for the medium and late groups and years were not significant in any case. The interaction between locations and cultivars was significant in all cases. It did not however, change cultivars rank, suggesting that the top selected genotypes would be best in most locations. Again, the indication is for selection towards broad adaptation cultivars.

No significance of the cultivar $\mathrm{x}$ sowing date interaction occurred concurrently with yield mean decrease when sowing was delayed from November to December, for the three maturity groups. This suggested absence of genetic variability for yield stability across sowings among the genotypes being tested in MT State. According to Lima et al. (2000), although variability for soybean adaptation to broad sowing date was obtained from most crosses, large sampling had to be used to allow selection of genotypes showing high and stable yield across sowing dates in Paraná State. Therefore, further investigative work on the available variability for wide range sowing dates and sample size is required in MT State to ensure successful selection. 


\section{Conclusions}

1. Locations are relatively more important than years for yield testing soybean genotypes in the Mato Grosso State; investment should be in increasing locations rather than years to increase the number of environments and to enhance experimental precision.

2. Partitioning the Mato Grosso State in regions has little or no impact on soybean yield testing and, consequently, on the efficiency of the soybean breeding program in the State.

3. Breeding genotypes with broad adaptation for the Mato Grosso State is an efficient strategy for cultivar development.

\section{References}

ALLARD, R.W.; BRADSHAW, A.D. Implications of genotypeenvironmental interactions in applied plant breeding. Crop Science, v.4, p.503-507, 1964.

ALLIPRANDINI, L.F.; TOLEDO, J.F.F. de; FONSECA JUNIOR, N.S.; ALMEIDA, L.A. de; KIIHL, R.A. de S. Análise de adaptação e estabilidade de genótipos de soja no Estado do Paraná. Pesquisa Agropecuária Brasileira, v.33, p.1321-1328, 1998.

ALLIPRANDINI, L.F.; TOLEDO, J.F.F. de; FONSECA JUNIOR, N.S.; ALMEIDA, L.A. de; KIIHL, R.A. de S. Efeitos da interação genótipo $\mathrm{x}$ ambiente sobre a produtividade da soja no Estado do Paraná. Pesquisa Agropecuária Brasileira, v.29, p.1433-1444, 1994.

ARANTES, N.E. Interação genótipo $\mathbf{x}$ ambiente e estudo de alternativas para seleção de variedades de soja [Glycine max (L.) Merril], com base em testes regionais. 1979. 65p. Dissertação (Mestrado) - Universidade Federal de Viçosa, Viçosa.
CARRARO, I.M.; SEDIYAMA, C.S.; ROCHA, A.; BAIRRÃO, J.F.M. Efeito da época de semeadura sobre a altura e o rendimento de doze cultivares de soja em Cascavel (PR). In: SEMINÁRIO NACIONAL DE PESQUISA DE SOJA, 3., 1984, Campinas. Anais. Campinas: Embrapa-CNPS, 1984. p.70-81.

CARVALHO, C.G.P. de; ARIAS, C.A.A.; TOLEDO, J.F.F. de; ALMEIDA, L.A. de; KIIHL, R.A. de S.; OLIVEIRA, M.F. de. Interação genótipo $\mathrm{x}$ ambiente no desempenho produtivo da soja no Paraná. Pesquisa Agropecuária Brasileira, v.37, p.989-1000, 2002.

CRUZ, C.D.; REGAZZI, A.J. Modelos biométricos aplicados ao melhoramento genético. Viçosa: UFV, 1994. 390p.

LIMA, W.F.; TOLEDO, J.F.F. de; ARIAS, C.A.A.; OLIVEIRA, M.F. de. Stability of soybean yield through different sowing periods. Pesquisa Agropecuária Brasileira, v.35, p.2181-2189, 2000.

MURAKAMI, D.M.; CRUZ, C.D. Proposta de metodologia para estratificação de ambientes e análise de adaptabilidade de genótipos. Crop Breeding and Applied Biotechnology, v.4, p.7-11, 2004.

RAMALHO, M.A.P.; SANTOS, J.B.; ZIMMERMANN, M.J.O. Genética quantitativa em plantas autógamas: aplicações ao melhoramento do feijoeiro. Goiânia: UFG, 1993. 271p.

STEEL, R.G.D.; TORRIE, J.H. Principles and procedures of statistics: a biometrical approach. Madison: McGraw-Hill, 1982. 633p.

TOLEDO, J.F.F. de; ARIAS, C.A.A.; OLIVEIRA, M.F. de; TRILLER, C.; MIRANDA, Z. de F.S. Genetical and environmental analyses of yield in six biparental soybean crosses. Pesquisa Agropecuária Brasileira, v.35, p.1783-1796, 2000.

TRILLER, C.; TOLEDO, J.F.F. de. Using the $F_{3}$ generation for predicting the breeding potential of soybean crosses. Brazilian Journal of Genetics, v.19, p.289-294, 1996.

URBEN FILHO, G.; SOUZA, P.I. de M. de. Manejo da cultura da soja sob cerrado: época, densidade e profundidade de semeadura. In: ARANTES, N.E.; SOUZA, P.I. de M. de. (Ed.). Cultura da soja nos cerrados. Piracicaba: Potafos, 1993. p.267-298.

$\overline{\text { Received on January 26, } 2005 \text { and accepted on January 10, } 2006}$ 